\title{
Why do households participate in the loan moratorium in Hungary? Theoretical and empirical considerations
}

\author{
BÁLINT DANCSIK* (1) and ZITA FELLNER (1)
}

Central Bank of Hungary (Magyar Nemzeti Bank - MNB), Szabadság tér 9, H-1054, Budapest, Hungary

Received: June 30, 2021 • Revised manuscript received: July 14, 2021 • Accepted: August 15, 2021

(C) 2021 Akadémiai Kiadó, Budapest

\begin{abstract}
In order to mitigate the economic effects from the COVID-19 epidemic, a moratorium on loan repayments was introduced in several countries, including Hungary. Essentially, a loan moratorium provides additional finance for participants, allowing theories of both credit demand and consumption to be tested on debtors' decisions as to whether or not they participate in the programme. In this paper, we use a linear probability model on the Hungarian survey data to examine the driving factors behind the households' decision to participate in the scheme. Our results show that the younger debtors and those with more children are more likely to utilise the programme. Stretched financial situations, i.e., lower incomes, lower savings and higher payment-to-income ratios, increase the probability of continued participation as well. The chance of participating in the scheme also increases significantly when a household has faced borrowing constraints over the past two years, i.e., it has not been or only partially been able to satisfy its credit demand.
\end{abstract}

\section{KEYWORDS}

Ioan moratorium, household finances, life-cycle, permanent income, borrowing, coronavirus, Hungary

\section{JEL CLASSIFICATION INDICES}

E21, G21, G51

\footnotetext{
*Corresponding author. E-mail: dancsikb@mnb.hu

The views expressed are those of the authors' and do not necessarily reflect the official view of the Central Bank of Hungary (MNB).
} 


\section{INTRODUCTION}

In order to mitigate the economic effects of the coronavirus epidemic, on 18 March 2020 the Hungarian Government decided to suspend the loan repayment obligations for retail and corporate debtors until the end of the year. The decision was by no means unique: similar measures were taken in 24 other countries in Europe (e.g., in Austria, Germany, Italy, Greece and Croatia (MNB 2020a), which was a good indication of the severity of the economic problem unfolding.

The moratorium in Hungary was automatically applicable to all debtors subject to the legislation. ${ }^{2}$ Debtors preferring not to remain in the scheme had the option of informing their credit institutions accordingly (by statement or implication, i.e. by continuing repayments) and exiting the scheme. ${ }^{3}$ In December 2020, a large number of debtors still took advantage of the option to suspend repayments: about $54 \%$ of the then eligible retail loan portfolio of credit institutions (approximately HUF 3,400 billion) and 39\% of the corporate loan portfolio (approximately HUF 2,700 billion) participated in the moratorium (MNB 2021a). The participating portfolio thus represented a significant amount compared to the banks' balance sheet $(\approx 11 \%)$ or to the annual GDP of the Hungarian economy $(13 \%)$.

We argue that, in practice, the moratorium on payments represents additional borrowing, for which debtors are automatically eligible subject to the terms set out in the legal regulations. Based on the theories on consumption and retail borrowing, we seek to identify the motivations for this "borrowing", i.e., for a debtor's decision to participate in the scheme. Our analysis in this study is limited to the motivations of retail debtors, but exploring the drivers of corporate debtors' decisions may be an equally interesting research question.

In the next part of the study, we present the cornerstones of the Hungarian moratorium on loan payments, along with the main impacts on debtors. We then present the main findings of the theoretical literature on household consumption (and its smoothing by borrowing). In the remainder of the study, after presenting the survey data used, we explain the estimation results of a linear probability model, the purpose of which is to identify the factors affecting participation in the moratorium. Our conclusions are presented at the end of the study.

\subsection{Key features of the Hungarian moratorium on payments}

In its original form, the moratorium on repayments concerned the suspension of debt service between 19 March and 31 December 2020, but it was eventually extended by the Government in a practically unchanged form until 30 June 2021, and then, by another three months until 30 September 2021. ${ }^{4}$ Debtors were not obliged to pay the instalments for this period at their due dates. However, unpaid instalments are not forgiven and must be settled subject to the following boundary conditions:

\footnotetext{
${ }^{2}$ Thus, the programme was designed with an "opt-out" logic. Introduction of the moratorium on payments was regulated by the Government Decrees 47/2020 (III.18.) and 62/2020 (III.24.).

${ }^{3} \mathrm{~A}$ debtor may also re-enter the scheme later.

${ }^{4}$ Government Decrees 637/2020 (XII.22.) and 317/2021 (VI.9).
} 
1. The instalment of a given loan may not increase after the expiry of the moratorium due to the postponement of payments. ${ }^{5}$

2. Interest repayments due during the moratorium are not capitalised and do not accrue interest and must be repaid by the customer in equal instalments (on a linear amortisation schedule) after the moratorium ends.

3. The remaining maturity $(n)$ is extended so that the conditions (1) and (2) can be met, as presented in equation $(1)^{6}$

$$
P=\left(C-\frac{P \times r \times t}{n}\right) \times\left(\frac{1-(1+r)^{-n}}{r}\right),
$$

where

$C$ denotes the forint value of the instalment paid by the debtor before entry into the programme, $P$ denotes the principal of the loan at the time of entry into the programme,

$r$ denotes the monthly interest rate,

$t$ denotes the number of months the debtor spent in the moratorium, $n$ denotes the extended maturity (months) when exiting the scheme.

These boundary conditions have a number of consequences. On the one hand, the debtor will repay the lending institution a nominally higher amount over the entire maturity due to the suspension of repayments (and, accordingly, as a result of the longer period during which interest accrues on the outstanding principal debt). On the other hand, as no interest is charged on deferred interest payments, the present value of the cash flows related to the loan is reduced, discounted by the original internal rate of return on the loan. In other words: the internal rate of return (which is basically the annual percentage rate of charge in the case of household loans) decreases. This latter fact also means that the participation in the moratorium causes a loss for the banks. ${ }^{7}$

In practice, in the case of a typical mortgage loan, the above amounts to an extension of approximately 14-15 months compared to the original maturity under the loan agreement due to the "original" moratorium expiring on 31 December 2020 (MNB 2020c), to which an additional 9-11 months are added due to the extension of the scheme for the first half of 2021. The full maturity extension can therefore reach up to two years in the case of a typical mortgage loan, of which 15 months are explained by participation in the moratorium, while approximately 9 months are required for the repayment of interest accrued as a result of the moratorium.

Looking at participation in and exit from the moratorium in terms of cash flows, it is easy to see that from a debtor's perspective remaining in the scheme essentially means additional borrowing. For fifteen months of repayments suspended "in the present", the customer pays

\footnotetext{
${ }^{5}$ However, in the case of variable-rate loans, the instalment may change (even increase) after expiry of the scheme, due to a change in the reference interest rate occurring during the debtor's participation in the moratorium.

${ }^{6}$ The equation states that the maturity should reach a length where it is true that the present value of the decreased instalments (reduced by the monthly linear amortisation of deferred interests) equals the nominal value of the principal debt.

${ }^{7}$ For 2020, the MNB (2020b) estimated the amount of that loss at approximately HUF 30 billion. Eventually, the loss actually incurred in 2020 was probably closer to HUF 50 billion, partly due to the fact that in 2020 some banks, taking a forward-looking approach, also accounted for the loss effect of the 2021 extension of the scheme.
} 
with $m$ months of additional repayments following the original maturity, where " $m$ " depends on two factors: the remaining maturity of the loan when entering the programme and the interest rate of the loan. If the customer had been required to continue with repayments, a similar situation would have been triggered by the customer covering instalments falling due during the moratorium period by taking out a new loan each month under the terms approximately equivalent to those of the original loan and repaying those loans after the original maturity (Table 1).

\subsection{Theoretical considerations (life-cycle hypothesis and permanent income)}

If participation in the moratorium is construed as a decision to borrow, we can draw on the past decades' literature on consumption and its smoothing. The vast majority of the modern consumption theories can be derived from papers by Modigliani - Brumberg (1954) and Friedman (1957). The main message of the two studies were similar: rather than depending on current income, people's consumption tended to depend on their "permanent" incomes spanning over life cycles.

According to the two theories and their extensions, ${ }^{8}$ consumers optimise their consumption in different periods so that their marginal utility remains the same in each period (Browning Crossley 2001). Simply put, this means that at life stages when the consumer's total income is lower than their "long-term" income, i.e., when they can expect an increase in income later on, consumption will exceed current income (Attanasio 1999). Conversely, where a decrease in income is expected, current income will exceed consumption. In the first case, the consumer's consumption in excess of their income must be covered by borrowing or from previous savings. Thus, while focussing on consumption, the theory also provides important insights into savings and the motivations for borrowing.

Since their inception, these theories have been improved in many respects. This was necessary because the empirical evidence did not support several conclusions of the theories, given the seemingly excessive correlation between consumption and current income. Several explanations have been offered for this discrepancy (Bertola et al. 2006):

- Changes in preferences: the structure of the household changes dramatically several times over the life cycle, which the consumer may not be able to predict accurately in earlier life stages. In reality, rather than a continuous life cycle, there exists a series of household types with varying preferences. In terms of consumption in the household, the biggest change is marked by the birth of children.

- Uncertainty about the future: if the marginal utility of consumption is described by a convex function, then greater value is attached by the consumer to safe consumption compared to consumption that has a similar expected value but is uncertain. In such a case, the consumer may make precautionary savings to offset the impact of future uncertainty in their income (Lugilde et al. 2019).

\footnotetext{
${ }^{8}$ In terms of theoretical foundations, one of the most important works is Hall (1978), where the Euler-equation is used to express the optimisation, including expectations, to be followed for consumption purposes. However, for empirical tests of the equation, the shape of the utility function is extremely relevant, and the function shapes used in each study can easily lead to different conclusions, simply as a result of the function chosen (quadratic, power, etc.) (Pignalosa 2018).
} 
Table 1. Schematic repayment paths with and without participation in the scheme

\begin{tabular}{|c|c|c|c|c|c|c|c|c|c|c|c|c|c|}
\hline & \multicolumn{5}{|c|}{ Moratorium } & \multicolumn{4}{|c|}{ Original maturity } & \multicolumn{4}{|c|}{ Maturity prolongation } \\
\hline & March 2020 & April 2020 & May 2020 & $(\ldots)$ & June 2021 & July 2021 & $(\ldots)$ & $\mathrm{T}-1$ & $\mathbf{T}$ & $\mathbf{T}+\mathbf{1}$ & $\mathbf{T}+\mathbf{2}$ & $(\ldots)$ & $\mathbf{T}+\mathbf{m}$ \\
\hline Cash flows - without moratorium & $-\mathrm{C}$ & $-\mathrm{C}$ & $-C$ & $(\ldots)$ & $-\mathrm{C}$ & $-\mathrm{C}$ & $(\ldots)$ & $-C$ & $-C$ & & & & \\
\hline Cash flows - with moratorium & & & & & & $-\mathrm{C}$ & $(\ldots)$ & $-C$ & $-C$ & $-\mathrm{C}$ & $-C$ & $(\ldots)$ & $-C$ \\
\hline Difference & $+\mathrm{C}$ & $+\mathrm{C}$ & $+\mathrm{C}$ & $(\ldots)$ & $+\mathrm{C}$ & - & - & - & - & $-C$ & $-C$ & $(\ldots)$ & $-\mathrm{C}$ \\
\hline
\end{tabular}

Note: $C$ denotes the size of the monthly instalment, $T$ denotes the original maturity date and $m$ denotes the required maturity extension. For the purpose of this schematic representation, we assume that the instalment is fixed in time (this will not necessarily hold in the case of a variable-rate loan), so the instalment amount is constant. In reality, instalments can also change due to changes in interest rates, and the last instalment may not be the same as the previous instalments.

Source: Authors' compilation. 
- Borrowing constraints: as banks tend to be selective about who they lend to, for certain consumer groups consumption may be restricted by their currently available liquid assets.

The drivers of borrowing have also been examined by empirical studies. Examining US data, Cox - Jappelli (1993) found that permanent income and net worth had a positive relationship with borrowing, while current income and age had a negative relationship with it. Also focusing on the US, Crook (2001) finds a positive correlation between credit demand and home ownership, family size and labour market status, and a negative correlation between net worth, age, risk aversion and borrowing. Looking at credit demand in the Spanish households, Manrique - Ojah (2004) also find credit demand to be decreasing with age, and to be increasing with progressively higher permanent incomes. The study also points to the existence of different drivers underlying demand for unsecured and secured loans. Del-Rio - Young (2005) confirm that lower age, higher income and favourable financial prospects increase the likelihood of participation in the unsecured credit market.

The additions to the theory are also confirmed by empirical evidences. For example, based on data from several countries, Crook (2006) demonstrates that the unemployed, who would be expected to present the highest demand for credit according to the theory of permanent income, tend to be absent from the credit market, presumably because of credit constraints. Jappelli Pagano (1989) argue that the size of credit constraints is significant: households affected by the credit constraints account for $12 \%$ of income in Sweden, $21 \%$ in the US, $40 \%$ in the UK and $58 \%$ in Italy. According to Grant (2007), 26-31\% of the US population was subject to credit constraints in the 1990s. In Hungary, the proportion of debtors below the median income is only $10-15 \%$ within new housing loans issued (MNB 2020b), another indication is that the sizeable social strata do not have access to formal financing.

In addition to consumption smoothing, it is important to discuss the motivations related to already outstanding debt. While a perfect financial market is assumed under the life-cycle model, in reality, consumers also need to make decisions about the loans that they have previously taken out, e.g., whether or not to suspend repayments and default. Under a rational model of default, in such cases a consumer will compare the utility and costs of default (Campbell - Cocco 2015). Arrears with repayments lead to additional consumption, but they may eventually result in high default interest, termination and enforcement against the debtor, social stigma and permanent exclusion from the credit market (Ganong - Noel 2020). Moreover, a consumer defaulting on a mortgage loan may lose the utility derived from the specific property involved (the "home").

For the purposes of the moratorium, this is significant because the scheme provides the debtor with access to liquidity which, after expiry of the scheme, may temporarily save them from incurring these costs. This too amounts to a form of precautionary "savings", but with the aim of avoiding financial difficulties and bankruptcy, rather than to smooth consumption in the classical sense.

In summary, it can be argued that in practical terms the moratorium represents a borrowing opportunity for debtors, which circumvents constraints on credit supply and is capped at the amount of each debtor's monthly instalments. Accepting that continued participation in the scheme can be considered as borrowing, the motivations listed above (consumption smoothing, precautionary savings and avoiding default) can also be tested. 
Under the theory, the following hypotheses may be expected to be fulfilled:

1. A decrease in income and higher uncertainty about likely changes in income lead to a greater willingness to participate. We expect negative changes in the labour market situation and a temporary deterioration in income, accompanied by higher uncertainty about income (employment in sectors particularly affected by the coronavirus), to increase the likelihood of continued participation in the scheme. This also relates to the fact that the debtors expecting to face financial difficulties are more likely to participate in the scheme. Lower income, higher payment-to income-ratios and higher debt can all raise the likelihood of the debtors participating in the scheme, in order to increase the chances of avoiding subsequently incurred costs associated with the late payment.

2. Debtors facing borrowing constraints are more likely to participate in the scheme. A debtor with additional demand for credit that could not (or is not expected to) be satisfied from another source is more likely to participate in the scheme.

3. Ceteris paribus, older age groups are less likely to participate in the scheme, while younger people are more likely to remain in the scheme. As older age groups can no longer count on increasing incomes, their demand for credit may be lower under the life-cycle hypothesis.

4. Lower lending interest rates may increase the likelihood of continued participation in the moratorium. In intertemporal decisions, the interest rate provides a connection between present and future consumption. The higher the interest rate on loans, the greater the sacrifice of present consumption growth expressed in terms of future consumption. High interest rates may therefore reduce the likelihood of borrowing, i.e., continued participation in the moratorium.

5. Consumers "living for the day" are more likely stay in the moratorium. In addition to the interest rate, the conversion between present and future consumption is determined by the discount rate characteristic of the consumer. A consumer who attaches a greater value to present consumption than to future consumption is more likely borrow, i.e. participate in the moratorium.

To date, both in Hungary and internationally, only a few studies have addressed which debtors have utilised the moratoriums, and why. Looking at the simple descriptive statistics on Irish mortgage loans, Gaffney - Greaney (2020) found that younger and more indebted debtors with previous payment difficulties are more likely to take advantage of rescheduled payments. Conducting a descriptive analysis on Hungarian data, the MNB (2020b) and Drabancz et al. (2021) also reported a higher willingness to participate by more indebted debtors with lower levels of educational attainment, lower incomes and lower savings. In the following, going beyond descriptive analysis, a linear probability model is used to examine these assertions.

\section{DATABASE AND METHODOLOGY}

To test our hypotheses, we rely on the survey conducted by the Magyar Nemzeti Bank (MNB) with contributions from major commercial banks and financial corporations. The online questionnaire was distributed to the households with debt outstanding with these institutions, 
and after the data were cleaned, ${ }^{9}$ the number of respondents was 36,310 . The questionnaire was completed by the households between 5 and 22 March 2021. At that point of time, the moratorium was expected to be terminated at the end of June 2021.

The questionnaire collected information on the following:

- Basic demographic information: county, type of municipality, age, educational attainment, size of household, number of dependents.

- Workplace information: type of employment for the main earner (full or part-time, selfemployed, etc.), sectoral information for household members.

- Financial and savings information: income, level of savings.

- Credit information: product type, identity of the disbursing bank, whether the household has one or more loans outstanding, amount of outstanding principal debts, payment-to-income ratios, any loan demand the debtor recently had and the extent to which that demand was met.

- Information on financial literacy and attitudes: general financial literacy, specific knowledge about how the moratorium works, attitude to money and savings.

- Impact of the coronavirus: whether the income/labour market situation of the debtor has deteriorated or improved during the coronavirus, expectations for the future.

While shaping the database used for the estimation, in order to handle multicollinearity, categories with a small number of observations were merged into the larger categories.

In the questionnaire, we specifically sought to capture debtors' financial literacy (including their knowledge about the moratorium), and their financial attitudes. Financial literacy was assessed through general quiz questions, which primarily related to knowledge about compound interest and inflation. Regarding the moratorium, we asked two questions to assess whether the debtor understands that, although the instalment will not increase due to the scheme after its expiry, maturity will be extended by more than the time of participation in the moratorium. Questions about financial attitude assessed debtors' attitudes towards savings and spending on a scale of $1-5$, and we averaged the responses to these questions to obtain a value for the debtor's attitudes. From each of these three variables we created a binary variable, where the financial literacy variable took the value of 1 if the debtor gave the correct answer to at least two of the three quiz questions. The value of our variable for the 'moratorium knowledge' was 1 if the debtor answered both questions correctly. Finally, in the case of our attitude variable, the values between 1-5 were cut at 4 , in view of the fact that the distribution of the responses was strongly shifted to the right (towards the saver's attitude).

\footnotetext{
${ }^{9}$ Before cleaning, a total of 47,000 retail debtors eligible for the moratorium had completed the questionnaire. Most of the questions consisted in a choice between predefined options, eliminating the need to control for outliers in the absence of continuous variables. On the one hand, data cleaning involved the screening of records where, for a relevant variable, the debtor answered "Do not know" or provided no answer, while we also disregarded debtors who only had some small credit line (credit card, overdraft facility) that could be also used for the transaction purposes, but no other debts. In the case of sectoral information, "other" answers have been classified if the respondent gave relevant information on the occupation. We also exclude those who took up a prenatal baby support loan, since these debtors may have confused the questionnaire about the COVID moratorium with the possible suspension of payments after the birth of their child in their case. The answers provided by the debtors of one bank were deleted from the database because based on the distribution of the respondents according to their participation in the moratorium, it was suspected that the bank only sent the questionnaire to customers which remained in the programme.
} 
For the purpose of identifying factors affecting staying in the moratorium, we estimated a linear probability model, the dependent variable for which was a binary variable indicating the use of the moratorium. When running the models, we handled heteroskedasticity by using robust standard errors. Multicollinearity was controlled for by calculating the variance inflation factor (VIF), and variables with high VIF values were also addressed, typically by merging categories.

\section{RESULTS}

The results of the estimated linear probability model are presented in Table 2. The households which experienced a deterioration in their income situation are more likely to continue their participation in the moratorium (7 percentage points more likely than those experiencing improvements in their income situation). This is also confirmed by our sectoral variables: where a member of the household is active in one of the sectors most affected by the coronavirus (accommodation, arts, entertainment), i.e., presumably earning below their "permanent" income, all else being equal, the probability of continued participation in the scheme increases by 5-8 percentage points. By contrast, in the households where a household member worked in a sector that can be considered "more secure" (e.g., administration, defence, health, social sector; electricity, water and waste management), debtors were more likely to exit the scheme.

Households with more stretched finances are also more likely to participate in the scheme. Those with debt service-to-income ratios (DSTI) above $40 \%$ are about 12 percentage points more likely to use the scheme than those with DSTI below $20 \%$. The likelihood of continued participation in the scheme was higher in the case of debtors with lower incomes and, all else being equal, also in the case of debtors with higher loan debt; however, the latter explanatory variable should be construed only in conjunction with the dummy variables for product types (given that the typical amount of debt varies significantly by credit type). ${ }^{10}$ Savings also matter: households with the capability to finance at least three months of their consumption from their savings are 4 percentage points less likely to remain in the scheme.

Households facing constraints on credit supply in the two years preceding the completion of the questionnaire are more likely to continue their participation in the moratorium. In our estimation, respondents who had previously been rejected by their banks are 9 percentage points more likely to remain in the scheme than the households which were granted credit, while those which have received only a smaller amount than requested are 6 percentage points more likely to use the moratorium. The largest impact can be identified for the debtors whose household would have had a demand for credit, but they did not even contact their bank because they were sure of being rejected (self-selection): they are 11 percentage points more likely to stay in the scheme. That means, that with the help of the moratorium, these households could obtain additional financing at a time when the credit supply of the banking system was decreasing. That is an indication that the moratorium was able to somewhat reduce the natural pro-cyclicality of the banking system.

\footnotetext{
${ }^{10}$ Accordingly, there is a relatively high correlation between the outstanding principal balance variable and the product type variables. To control for any bias that may occur due to this, we also run the model with the outstanding principal balance variable eliminated but do not obtain any meaningful change in our results.
} 
Table 2. Estimating the motivations for participation in the moratorium using a linear probability model (dependent variable: 1 = the household stays in the moratorium)

\begin{tabular}{|c|c|}
\hline Explanatory variables & Coefficients \\
\hline \multirow[t]{2}{*}{ The respondent understands how the moratorium works (1-Yes) } & $0.0408^{* * *}$ \\
\hline & $(0.00485)$ \\
\hline \multirow[t]{2}{*}{ Financial knowledge score } & 0.00829 \\
\hline & $(0.00590)$ \\
\hline \multirow[t]{2}{*}{ Saver's attitude (1-Yes) } & $-0.0362 * * *$ \\
\hline & $(0.00506)$ \\
\hline \multicolumn{2}{|l|}{ Main earner's age (Reference: $18-34$ years) } \\
\hline \multirow[t]{2}{*}{$35-44$ years } & $-0.0619 * * *$ \\
\hline & $(0.00775)$ \\
\hline \multirow[t]{2}{*}{$45-54$ years } & $-0.0695 * * *$ \\
\hline & $(0.00758)$ \\
\hline \multirow[t]{2}{*}{$55-64$ years } & $-0.102 * * *$ \\
\hline & $(0.00861)$ \\
\hline \multirow[t]{2}{*}{65 years and over } & $-0.114 * * *$ \\
\hline & $(0.0111)$ \\
\hline \multicolumn{2}{|l|}{$\begin{array}{l}\text { Educational level (Reference: Vocational secondary school, } 8 \text { years } \\
\text { of primary schooling or lower) }\end{array}$} \\
\hline \multirow[t]{2}{*}{ Secondary grammar school } & $-0.0192 * * *$ \\
\hline & $(0.00691)$ \\
\hline \multirow[t]{2}{*}{ High-level vocational education } & $-0.0288 * * *$ \\
\hline & $(0.00914)$ \\
\hline \multirow[t]{2}{*}{ College, university } & $-0.0275^{* * *}$ \\
\hline & $(0.00749)$ \\
\hline \multicolumn{2}{|l|}{ Number of children (Reference: no child) } \\
\hline \multirow[t]{2}{*}{ One child } & $0.0543^{* * *}$ \\
\hline & $(0.00607)$ \\
\hline \multirow[t]{2}{*}{ Two children } & $0.0548^{* * *}$ \\
\hline & $(0.00716)$ \\
\hline \multirow[t]{2}{*}{ Three or more children } & $0.109 * * *$ \\
\hline & $(0.0105)$ \\
\hline
\end{tabular}


Table 2. Continued

\begin{tabular}{|c|c|}
\hline Explanatory variables & Coefficients \\
\hline \multicolumn{2}{|l|}{ Type of municipality (Reference: Budapest) } \\
\hline \multirow[t]{2}{*}{ County seat, city with county authority } & $0.0336 * *$ \\
\hline & $(0.0169)$ \\
\hline \multirow[t]{2}{*}{ Other city/town } & 0.0242 \\
\hline & $(0.0164)$ \\
\hline \multirow[t]{2}{*}{ Rural municipality } & $0.0391 * *$ \\
\hline & $(0.0168)$ \\
\hline \multicolumn{2}{|c|}{ Payment to income ratio (Reference: $0-20 \%$ ) } \\
\hline \multirow[t]{2}{*}{$21-40 \%$} & $0.0588 * * *$ \\
\hline & $(0.00549)$ \\
\hline \multirow[t]{2}{*}{ More than $40 \%$} & $0.115^{* * *}$ \\
\hline & $(0.00872)$ \\
\hline \multicolumn{2}{|l|}{ Loan product type } \\
\hline \multirow[t]{2}{*}{ Housing loan } & $-0.0647 * * *$ \\
\hline & $(0.00655)$ \\
\hline \multirow[t]{2}{*}{ Home equity mortgage loan } & $0.0390 * * *$ \\
\hline & $(0.00728)$ \\
\hline \multirow[t]{2}{*}{ Personal loan } & $0.138 * * *$ \\
\hline & $(0.00674)$ \\
\hline \multirow[t]{2}{*}{ Car purchase loan } & $-0.0170 * *$ \\
\hline & $(0.00732)$ \\
\hline \multirow[t]{2}{*}{ Commodity loan } & 0.00344 \\
\hline & $(0.00729)$ \\
\hline \multirow[t]{2}{*}{ Overdraft } & $0.0465^{* * *}$ \\
\hline & $(0.00513)$ \\
\hline \multirow[t]{2}{*}{ Credit card loan } & $0.0273^{* * *}$ \\
\hline & $(0.00488)$ \\
\hline \multirow[t]{2}{*}{ Several loan types } & $0.0555^{* * *}$ \\
\hline & $(0.00682)$ \\
\hline
\end{tabular}


Table 2. Continued

\begin{tabular}{|c|c|}
\hline Explanatory variables & Coefficients \\
\hline \multicolumn{2}{|c|}{ Outstanding principal debt (Reference: below HUF 500,000) } \\
\hline \multirow[t]{2}{*}{ HUF $500,000-1,000,000$} & 0.00813 \\
\hline & $(0.00937)$ \\
\hline \multirow[t]{2}{*}{ HUF $1,000,000-3,000,000$} & $0.0783^{* * *}$ \\
\hline & $(0.00763)$ \\
\hline \multirow[t]{2}{*}{ HUF $3,000,000-5,000,000$} & $0.123 * * *$ \\
\hline & $(0.00865)$ \\
\hline \multirow[t]{2}{*}{ HUF $5,000,000-10,000,000$} & $0.170 * * *$ \\
\hline & $(0.00879)$ \\
\hline \multirow[t]{2}{*}{ HUF $10,000,000-20,000,000$} & $0.244 * * *$ \\
\hline & $(0.0102)$ \\
\hline \multirow[t]{2}{*}{ above HUF $20,000,000$} & $0.334 * * *$ \\
\hline & $(0.0138)$ \\
\hline \multicolumn{2}{|c|}{ Household income (Reference: below HUF 200,000) } \\
\hline \multirow[t]{2}{*}{ HUF $200,000-300,000$} & $-0.0758 * * *$ \\
\hline & $(0.00859)$ \\
\hline \multirow[t]{2}{*}{ HUF $300,000-400,000$} & $-0.141 * * *$ \\
\hline & $(0.00893)$ \\
\hline \multirow[t]{2}{*}{ HUF $400,000-500,000$} & $-0.192 * * *$ \\
\hline & $(0.00939)$ \\
\hline \multirow[t]{2}{*}{ HUF 500,000-750,000 } & $-0.254 * * *$ \\
\hline & $(0.00970)$ \\
\hline \multirow[t]{2}{*}{ HUF $750,000-1,000,000$} & $-0.280 * * *$ \\
\hline & $(0.0120)$ \\
\hline \multirow[t]{2}{*}{ above HUF $1,000,000$} & $-0.313^{* * *}$ \\
\hline & $(0.0136)$ \\
\hline \multicolumn{2}{|c|}{ Savings (Reference: less than 3 months) } \\
\hline \multirow[t]{2}{*}{ Covers more than 3 months } & $-0.0437 * * *$ \\
\hline & $(0.00541)$ \\
\hline
\end{tabular}

(continued) 
Table 2. Continued

\begin{tabular}{|c|c|}
\hline Explanatory variables & Coefficients \\
\hline \multicolumn{2}{|l|}{ Change in income since the outbreak (Reference: deteriorated) } \\
\hline \multirow[t]{2}{*}{ No substantial change } & $-0.142 * * *$ \\
\hline & $(0.00542)$ \\
\hline \multirow[t]{2}{*}{ Improved } & $-0.0731 * * *$ \\
\hline & $(0.00903)$ \\
\hline \multicolumn{2}{|l|}{$\begin{array}{l}\text { Expected change in financial situation over the one year ahead } \\
\text { (Reference: expected to deteriorate) }\end{array}$} \\
\hline \multirow[t]{2}{*}{ No substantial change expected } & $0.0607^{* * *}$ \\
\hline & $(0.00561)$ \\
\hline \multirow[t]{2}{*}{ Expected to improve } & $0.106 * * *$ \\
\hline & $(0.00772)$ \\
\hline \multicolumn{2}{|l|}{$\begin{array}{l}\text { Any rejected loan applications in the past two years (Reference: } \\
\text { submitted applications, no rejections) }\end{array}$} \\
\hline \multirow[t]{2}{*}{ No Ioan applications } & $0.0228 * * *$ \\
\hline & $(0.00523)$ \\
\hline \multirow[t]{2}{*}{ Granted a lower amount than requested } & $0.0629 * * *$ \\
\hline & $(0.0129)$ \\
\hline \multirow[t]{2}{*}{ No application submitted because the bank would have rejected it } & $0.114 * * *$ \\
\hline & $(0.0139)$ \\
\hline \multirow[t]{2}{*}{ Rejections occurred } & $0.0946 * * *$ \\
\hline & $(0.00920)$ \\
\hline \multicolumn{2}{|l|}{ Sector of activity of household members } \\
\hline \multirow[t]{2}{*}{ Not working } & $0.0364 * * *$ \\
\hline & $(0.0109)$ \\
\hline \multirow[t]{2}{*}{ Administrative activities } & 0.0146 \\
\hline & $(0.00938)$ \\
\hline \multirow[t]{2}{*}{ Construction industry } & $-0.0211 * *$ \\
\hline & $(0.00876)$ \\
\hline \multirow[t]{2}{*}{ Machine industry } & 0.0108 \\
\hline & $(0.00868)$ \\
\hline
\end{tabular}


Table 2. Continued

\begin{tabular}{|c|c|}
\hline Explanatory variables & Coefficients \\
\hline \multirow[t]{2}{*}{ Chemical industry, metallurgy } & -0.0244 \\
\hline & $(0.0156)$ \\
\hline \multirow[t]{2}{*}{ Food industry } & -0.00559 \\
\hline & $(0.0123)$ \\
\hline \multirow[t]{2}{*}{ Light industry } & -0.00190 \\
\hline & $(0.00968)$ \\
\hline \multirow[t]{2}{*}{ Information and communication } & $-0.0195^{* *}$ \\
\hline & $(0.00863)$ \\
\hline \multirow[t]{2}{*}{ Trade and repair of motor vehicles } & -0.00308 \\
\hline & $(0.00738)$ \\
\hline \multirow[t]{2}{*}{ Administration, defence, health, social sector } & $-0.0287 * * *$ \\
\hline & $(0.00622)$ \\
\hline \multirow[t]{2}{*}{ Agriculture, forestry and fishing } & -0.00566 \\
\hline & $(0.0138)$ \\
\hline \multirow[t]{2}{*}{ Arts, entertainment, leisure } & $0.0511 * * *$ \\
\hline & $(0.0139)$ \\
\hline \multirow[t]{2}{*}{ Education } & -0.00319 \\
\hline & $(0.00738)$ \\
\hline \multirow[t]{2}{*}{ Finance } & $-0.0367 * * *$ \\
\hline & $(0.00862)$ \\
\hline \multirow[t]{2}{*}{ Professional and scientific activities } & $-0.0231 * *$ \\
\hline & $(0.0109)$ \\
\hline \multirow[t]{2}{*}{ Transportation and storage } & -0.0101 \\
\hline & $(0.00820)$ \\
\hline \multirow[t]{2}{*}{ Accommodation and services } & $0.0769 * * *$ \\
\hline & $(0.0115)$ \\
\hline \multirow[t]{2}{*}{ Electricity, water and waste management } & $-0.0330 * *$ \\
\hline & $(0.0135)$ \\
\hline \multirow[t]{2}{*}{ Services } & $0.0559 * * *$ \\
\hline & $(0.0190)$ \\
\hline
\end{tabular}

(continued) 
Table 2. Continued

\begin{tabular}{|l|c|}
\hline Explanatory variables & Coefficients \\
\hline Bank dummy & not given \\
\hline County dummy & not given \\
\hline Constant & $0.319 * * *$ \\
\cline { 2 - 2 } & $(0.0251)$ \\
\hline Observations & 36,310 \\
\hline R-squared & 0.252 \\
\hline
\end{tabular}

Note: Robust standard errors in parentheses. ${ }^{* *} \mathrm{p}<0.01,{ }^{* *} \mathrm{p}<0.05, * \mathrm{p}<0.1$. Coefficients of bank and county dummies are not given due to data security issues.

Source: Authors' compilation.

Consistently with the life-cycle hypothesis, older age groups are more likely to exit the scheme than younger debtors. Households with a main earner over 65 are 11 percentage points less likely to use the moratorium than the households with main earners aged 18-34. The number of children also significantly influences participation in the scheme: with three or more children, the likelihood of participation is nearly 11 percentage points higher compared to households without children. Conversely, although the coefficients of its variable are significant, educational attainment is not a major driver of participation in the scheme.

Our hypothesis that loans with higher interest rates are less likely to remain in the moratorium is not confirmed. In view of the fact that the questionnaire did not include a question on the interest rate of specific loans, ${ }^{11}$ we can only rely on the product types to approximate interest payable. Housing loans typically have lower interest rates, while the rates on personal loans and other consumer loans tend to be higher. ${ }^{12}$ We expect that we should see a negative coefficient in the case of these products after controlling for their other relevant characteristics. ${ }^{13}$

However, according to the results of the model, the probability of the debtors with personal loans continuing their participation in the scheme is still 14 percentage points higher than for the debtors without personal loans. The reason for that is probably the failure of our financial attitude variable to adequately capture consumers' carpe diem attitude, and in many cases, respondents gave the answer they thought was correct, not the answer that is characteristic of their behaviour. The "real" attitude is thus largely reflected in the type of loans taken; therefore, the discount rate ensuring the conversion between current and future consumption is also

\footnotetext{
${ }^{11}$ This is because previous surveys revealed that the Hungarian households had an extremely inaccurate understanding of the interest charged on their loans (MNB 2019, pp 63-65). For example, less than 40 per cent of the population knows that APRCs are higher than interest rates on loans, and only one-third was able to estimate the magnitude of the impact of a 1 percentage point rise in the interest rate on the monthly instalment.

${ }^{12}$ Detailed data are presented in the interest rate statistics of the MNB. https://www.mnb.hu/statisztika/statisztikaiadatok-informaciok/adatok-idosorok/xi-deviza-penz-es-tokepiac.

${ }^{13}$ Consumer loans are typically taken out by customers with lower incomes and tend to have higher DSTI ratios compared to housing loans.
} 
incorporated in these variables. This is confirmed by the fact that if the attitude variable is excluded from the model, the coefficient of consumer credit types does not change markedly. ${ }^{14}$

Nevertheless, the coefficient of our attitude variable points in the right (negative) direction: that is, households that attach a greater value to savings and tend to spend their money less readily are more likely to exit the scheme. Our variable for general financial literacy proved to be insignificant, while answering the questions related to the moratorium correctly was found to increase the chances of a debtor participating in the moratorium. However, there is potentially a reverse causality underlying the latter finding, i.e., for those who remained in the scheme it may have been more important to explore the consequences. ${ }^{15}$

Changes in household income since the coronavirus and the forward-looking expectations of the household also produced interesting results. Where the household's income position improved since the coronavirus, this acted as a driver towards exiting, but to a lesser extent than for the households with no meaningful change in income (in both cases, the reference group being the households with deteriorating income positions). As for forward-looking expectations, regardless whether the household expects no change or an improvement in its financial position, the likelihood of participation in the scheme increases in both cases. This, in turn, raises the problem of reverse causality, i.e., where a household considers participation in the moratorium to be a "part" of its financial position, any improvement in that position could merely be a consequence of remaining in the scheme.

The change in the income position since the coronavirus and expectations about the financial position are also examined in interaction with each other in order to identify the dynamics between the two variables. The coefficients of this interaction are summarised in Fig. 1, whereas the coefficients of the other variables in this model are not published due to space limitations. The results show that in the households experiencing a deterioration in their income positions since the coronavirus, the likelihood of remaining in the scheme is the highest where an improvement in the income position is expected in the short term. This is consistent with the life-cycle hypothesis, since credit demand (i.e., willingness to participate in the moratorium) occurs where income only temporarily falls short of permanent income. For households where income has not changed significantly since the coronavirus outbreak, debtors are more likely to exit the scheme. One possible explanation could be that in cases where the pandemic did not lead to a substantial change in the household incomes and expectations, the volume of borrowing may already have been optimal before the outbreak, and there was no need for the household to supplement it by means of the moratorium. Finally, among the households with improved income positions, the likelihood of remaining in the scheme is the highest where a deterioration in the position is expected in the near future. Their choice may be dominated by a precautionary motivation. However, it is also important to underline that this part of the questionnaire is only partially suitable for testing the life-cycle hypothesis, since from the perspective of the theory, what matters is not really whether the income of the debtor has

\footnotetext{
${ }^{14}$ To conduct a robustness test, the role of the interest rate was also examined on factual data, based on the Central Credit Information System and related databases. The results are presented in the next section of the paper.

${ }^{15}$ To verify this, we also run the model on a sample excluding those who exited the scheme at the very beginning of the moratorium. The coefficient of the variable remained positive and significant, although it decreased.
} 


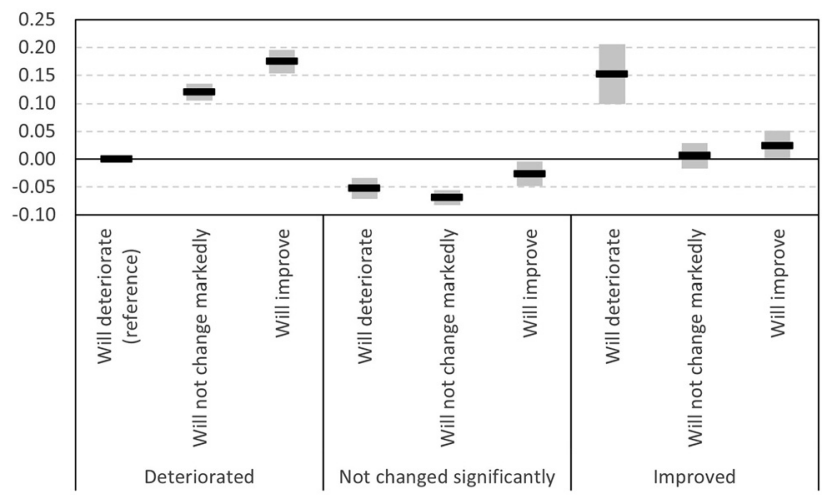

Note: The estimated coefficient is marked by a black line, and the grey range indicates the $95 \%$ confidence interval.

Fig. 1. Coefficients of the interactions between the two variables describing how the income of the household have changed since the COVID and how it is expected to change in the next year

increased or decreased since the coronavirus, but whether their expected income path has changed as a result of the outbreak, and if so, in which direction.

\section{ROBUSTNESS}

In order to support our estimation results, we also performed two types of robustness test. On the one hand, in addition to the questionnaire data presented above, we checked our results in three other model frameworks. We run logit and probit models, and also estimated the linear probability model in a version where the weighting of the sample was more representative of the entire population. On the other hand, reaching beyond the scope of our questionnaire data, we check the previous results on the data of approximately 345,000 loan contracts by including the variables available for factual data based on bank disclosures.

\subsection{Other model types - logit, probit and weighted linear probability model}

In addition to the inclusion of the same dependent variable and the same independent variables, logit and probit models were run on the questionnaire data, and the linear probability model was also estimated by weighting the observations. Weighting was by product type (taking into account the following products: mortgage loan, personal loan, car purchase loan, and commodity loan) and moratorium status, applying weights based on official bank disclosures. However, it should be underlined that the basic units of bank disclosures are the debtor and the loan agreement, while in our questionnaire data the household is the basic unit, whereby weighting will not accurately map the real population distributions.

There are no significant differences in the direction, magnitude and significance of the coefficients in either model framework. ${ }^{16}$ In the case of the weighted model, the coefficients of the

\footnotetext{
${ }^{16}$ For further information related to the results of these models, please contact the authors.
} 
product types change substantially, in particular in the case of home equity mortgage loans, where the previously positive coefficient change in the negative direction. This may be due to the fact that during the weighting, mortgage loans were taken into account as a group, without separating housing and home equity products. Overall, we consider that the estimates obtained in the other model frameworks confirm our main results.

\subsection{Modelling on factual data based on bank disclosures}

The estimation procedure based on the questionnaire data involves the disadvantage of potential sample bias from both the method of data collection (online questionnaire) and inaccurate answers by the respondents. As such bias will not occur in the micro-level databases provided by the banks, we consider it reasonable to examine whether the previously explained connections also apply when these databases are used. However, these databases are less versatile compared to our questionnaire data: they contain fewer variables, which, conversely, are mostly continuous and not category variables.

For our robustness analysis, a logit model is estimated on a sample created by combining several micro-level databases (L10, L11 and HITREG disclosures to the MNB, personal income tax database from the Tax Administration, employment data from the Central Administration of National Pension Insurance) in an anonymous manner, in which the credit information (contract type, principal outstanding and interest rate) and the information on the debtor (the debtor's income at the time of disbursement and the debt-to-income ratio, occupation, number of children and age) are included. In the database, the observation unit is the contract. In the model, the dependent variable took the value of 1 where the given contract participated in the moratorium. The impact of the pandemic on the debtor's finances could not be examined on this sample.

The research question is examined by the reference to the intersection of the above databases. Thus, our estimation examines the possible influencing factors of staying in the moratorium for mortgage and personal loans (about 345,000 contracts) disbursed between 2015 and 2019. The research question is examined by cross-sectional logistic regression, i.e., the following model is estimated:

$$
P\left(y_{i}=1\right)=\frac{e^{\alpha+\beta X_{i}}}{1+e^{\alpha+\beta X_{i}}}
$$

where $y_{i}$ is a binary variable indicating whether the debtor remains in the moratorium, and $X_{i}$ denotes the vector of the independent variables used for the $i$ th contract. The model is estimated separately by product type (mortgage vs. personal loan). The model incorporates the following independent variables:

- product type (housing loan/home equity mortgage loan/personal loan)

- is the contracted debtor's job vulnerable to the coronavirus? (1: yes, $0:$ no) ${ }^{17}$

- average age of debtors and co-debtors under the contract

\footnotetext{
${ }^{17}$ To determine vulnerability, we use the classification in the MNB's Financial Stability Report of June 2021 (MNB $2021 \mathrm{~b}$ Box 6).
} 
Table 3. Logistic regression results - average marginal effects (Target variable: participation in the moratorium)

\begin{tabular}{|l|c|c|c|}
\hline & $\begin{array}{c}\text { Mortgage and } \\
\text { personal loan } \\
(\boldsymbol{n}=\mathbf{3 4 5} \mathbf{2 4 3})\end{array}$ & $\begin{array}{c}\text { Mortgage } \\
\text { loan only } \\
(\boldsymbol{n}=\mathbf{1 8 4} 705)\end{array}$ & $\begin{array}{c}\text { Personal } \\
\text { loan only } \\
(\boldsymbol{n}=\mathbf{1 6 0} 536)\end{array}$ \\
\hline Home equity m. dummy (housing loan $=0)$ & $0.107^{* * *}$ & $0.119^{* * *}$ & \\
\hline Personal loan dummy (housing loan $=0)$ & $0.270^{* * *}$ & & \\
\hline Vulnerable job & $0.011^{* * *}$ & $0.007^{* * *}$ & $0.012^{* * *}$ \\
\hline Average age & $-0.003^{* * *}$ & $-0.001^{* * *}$ & $-0.004^{* * *}$ \\
\hline Number of children & $0.018^{* * *}$ & $0.023^{* * *}$ & $0.012^{* * *}$ \\
\hline Income per capita (logarithmic) & $-0.049^{* * *}$ & $-0.034^{* * *}$ & $-0.051^{* * *}$ \\
\hline Payment-to-income indicator & $0.002^{* * *}$ & $0.003^{* * *}$ & $0.000^{* * *}$ \\
\hline Outstanding principal balance (logarithmic) & $0.075^{* * *}$ & $0.067^{* * *}$ & $0.089 * * *$ \\
\hline Interest rate (logarithmic) & $0.117^{* * *}$ & $0.035^{* * *}$ & $0.202^{* * *}$ \\
\hline County seat (capital $=0)$ & $-0.037^{* * *}$ & $-0.026^{* * *}$ & $-0.053^{* * *}$ \\
\hline Other municipalities (capital $=0)$ & $-0.018^{* * *}$ & $0.011^{* * *}$ & $-0.051^{* * *}$ \\
\hline Bank control dummies & $\sqrt{ }$ & $\sqrt{ }$ & $\sqrt{ }$ \\
\hline
\end{tabular}

Note: $* * *$ Denotes results that are significant at a significance level of $1 \%$. Standard errors robust for heteroscedasticity.

Source: Authors' compilation.

- number of children dependent on the debtors and co-debtors under the contract ${ }^{18}$

- logarithm of income per debtor (at the time of disbursement) ${ }^{19}$

- payment-to-income ratio at the time of disbursement of the loan

- logarithm of outstanding principal balance

- logarithm of interest rate

- whether the debtor was a resident in the capital (1: yes, 0: no)

- whether the debtor was a resident in a county seat (1: yes, $0:$ no)

- whether the debtor was a resident in a town or village (1: yes, $0:$ no)

- disbursing bank (one binary variable for each bank, taking the value of 1 for one institution per transaction, and 0 otherwise)

The results of the estimated logistic regressions confirmed the results obtained from the questionnaire data. Variables potentially indicating strained liquidity increase the likelihood

\footnotetext{
${ }^{18}$ Data on the number of children were only available for debtors who had loans at the end of 2018 . This mainly narrows down the sample of debtors with personal loans. However, we also run the model on a larger sample without the "number of children" variable, and the significance and sign of coefficients do not change.

${ }^{19}$ Given that our income data were only available for debtors and co-debtors collectively, we consider income per debtor to address the size differences arising from the number of debtors.
} 
of continued participation in the moratorium. These variables include, for example, the vulnerability of the debtor's job, the number of dependent children, the amount of outstanding principal balance and the debt-to-income ratio. The likelihood of remaining also increases with loans taken for consumption-type purposes: in comparison to housing loans, both home equity mortgage loans and personal loans are significantly more likely to participate in the scheme even after controlling for other variables in the model. By contrast, higher income and higher age have a moderating effect on the likelihood of participation in the moratorium.

Another advantage of the estimation being based on bank data is that it also allows for an examination of the impact of the interest rate, rather than proxy variables to approximate it. The logarithm of the interest rate received a positive coefficient, which may indicate that due to strained liquidity, the utility of the liquidity released may outweigh the higher costs associated with the higher interest rate. The positive coefficient may also reflect a correlation between the client's discount rate and the interest rate on the loan, i.e. that debtors borrowing at higher interest rates tend to be debtors who, compared to future consumption, attach a sufficiently greater value to current consumption to be willing to pay a higher price for current consumption (see Table 3).

\section{CONCLUSION}

In this study, we argued that participation in a loan repayment moratorium is similar to additional borrowing, which allows theories of credit demand to be tested on the debtors' decisions about participating in the programme. This was done in the context of the Hungarian retail loan moratorium on a questionnaire sample of 36,310 respondents, using a linear probability model.

Our results showed that, consistently with the life-cycle hypothesis, younger households and households with more children stayed in the scheme in higher proportions. Stretched finances also play a significant role: households with higher payment-to-income ratios and lower incomes are more likely to avail themselves of the scheme, as are debtors whose income situation deteriorated during the pandemic and who are active in sectors particularly sensitive to the economic effects of the pandemic.

Interestingly, households that in the preceding two years had submitted a loan application that was at least partially rejected were significantly more likely to use the scheme compared to those that had not faced the credit supply constraints. This result points directly to the fact that the moratorium on loan repayments not only provides additional liquidity for its participants, but may also partly satisfy economic agents' demand for credit at a time when credit supply constraints are particularly severe; that is, the scheme may be capable of reducing the procyclicality of the banking system.

\section{ACKNOWLEDGEMENT}

We would like to thank Gergely Fábián, Tamás Nagy, Ádám Banai, Anna Marosi and Nikolett Vágó for useful comments and support. 


\section{REFERENCES}

Attanasio, O. P. (1999): Consumption. In: Taylor, J. B. - Woodford, M. (eds): Handbook of Macroeconomics, Vol. I. Elsevier Science B. V., pp. 742-812.

Bertola, G. - Disney, R. - Grant, C. (2006): The Economics of Consumer Credit Demand and Supply. In: Bertola, G. - Disney, R. - Grant, C. (eds): The Economics of Consumer Credit. The MIT Press, pp. 1-26.

Browning, M. - Crossley, T. F. (2001): The Life-Cycle Model of Consumption and Saving. Journal of Economic Perspectives, 15(3): 3-22.

Campbell, J. Y. - Cocco, J. F. (2015): A Model of Mortgage Default. The Journal of Finance, 70(4): 14951554.

Cox, D. - Jappelli, T. (1993): The Effect of Borrowing Constraints on Consumer Liabilities. Journal of Money, Credit and Banking, 25: 197-203.

Crook, J. N. (2001): The Demand for Household Debt in the USA: Evidence from the 1995 Survey of Consumer Finance. Applied Financial Economics, 11(1): 83-91.

Crook, J. N. (2006): Household Debt Demand and Supply: A Cross-Country Comparison. In Bertola, G. Disney, R. - Grant, C. (eds): The Economics of Consumer Credit. The MIT Press, pp. 93-134.

Drabancz, Á. - Grosz, G. - Palicz, A. - Varga, B. (2021): A fizetési moratórium bevezetésének magyarországi tapasztalatai (Lessons Learned from a Payments Moratorium in Hungary). Hitelintézeti Szemle, 20(1): 5-42.

Del-Rió, A. - Young, G. (2005): The Determinants of Unsecured Borrowing: Evidence from the British Household Panel Survey. Bank of England Working Paper, No. 263.

Friedman, M. (1957): A Theory of the Consumption Function. Princeton University Press.

Gaffney, E. - Greaney, D. (2020): COVID-19 Payment Breaks on Residential Mortgages. Financial Stability Note, No. 2020/5, Central Bank of Ireland.

Ganong, P. - Noel, P. (2020): Why do Borrowers Default on Mortgages? A New Method for Causal Attribution. NBER Working Paper, No. 27585.

Grant, C. (2007): Estimating Credit Constraints Among US Households. Oxford Economic Papers, 59: 583605.

Hall, R. E. (1978): Stochastic Implications of the Life Cycle-Permanent Income Hypothesis: Theory and Evidence. Journal of Political Economy, 86(6): 971-987.

Jappelli, T. - Pagano, L. (1989): Consumption and Capital Market Imperfections: An International Comparison. The American Economic Review, 79(5): 1088-1105.

Lugilde, A. - Bande, R. - Riveiro, D. (2019): Precautionary Saving: A Review of the Empirical Literature. Journal of Economic Surveys, 33(2): 481-515. https://doi.org/10.1111/joes.12284.

Manrique, J. - Ojah, K. (2004): Credits and Non-Interest Rate Determinants of Loan Demand: A Spanish Case Study. Applied Economics, 36(8): 781-791.

Modigliani, F. - Brumberg, R. H. (1954): Utility Analysis and the Consumption Function: An Interpretation of Cross-Section Data. In: Kurihara, K. K. (ed.): Post Keynesian Economics. Rutgers University Press, pp. 388-436.

MNB (2019): Financial Stability Report, May 2019. Budapest: Magyar Nemzeti Bank.

MNB (2020a): Macroprudential Report, 2020. Budapest: Magyar Nemzeti Bank.

MNB (2020b): Financial Stability Report, November 2020. Budapest: Magyar Nemzeti Bank.

MNB (2020c): Financial Stability Report, May 2020. Budapest: Magyar Nemzeti Bank.

MNB (2021a): Trends in Lending, March 2021. Budapest: Magyar Nemzeti Bank. 
MNB (2021b): Financial Stability Report, June 2020. Budapest: Magyar Nemzeti Bank.

Pignalosa, D. (2018): On the Role of the Utility Function in the Estimation of Preference Parameters. Metroeconomica, 70(4): 793-820. 